\title{
Aneurysm of the Fenestrated Basilar Artery: Case Report and Literature Review
}

\section{Aneurisma de artéria basilar fenestrada: relato de caso e revisão da literatura}

\author{
Linoel Curado Valsechi ${ }^{1}$ Lucas Crociati Meguins ${ }^{1}$ Isabela Pinho Tigre Maia ${ }^{1}$ Adil Bachir Fares ${ }^{1}$ \\ Diogo Andre Taffarel ${ }^{1}$ Raquel Cristina Trovo Hidalgo ${ }^{1}$
}

${ }^{1}$ Division of Neurosurgery, School of Medicine, Faculdade de Medicina de São Jose do Rio Preto, São Jose do Rio Preto, SP, Brazil

Arq Bras Neurocir 2017;36:225-229.
Address for correspondence Linoel Curado Valsechi, MD, Faculdade de Medicina de São Jose do Rio Preto, São Jose do Rio Preto,

SP, 15090-000, Brazil (e-mail: Icvalsechi@gmail.com).

\begin{abstract}
Keywords

- intracranial aneurism

- subarachnoid hemorrhage

- cerebral angiography

- fenestration

Introduction Aneurysms of the vertebrobasilar junction are rare, but when present, they are often associated with fenestration of the basilar artery. Frequently, the endovascular treatment is the first choice due to the complex anatomy of the posterior fossa, which represents a challenge for the open surgical treatment alternative.

Case Report A 47-year-old man was admitted to the emergency unit with headache, diplopia, neck pain and mental confusion. The neurological exam showed: score of 15 in the Glasgow coma scale (GCS), no motor or sensitivity deficit, palsy of the left sixth cranial nerve and Hunt-Hess grade III. The computed tomography (CT) scan showed subarachnoid hemorrhage (Fisher III) and hydrocephalus. The patient was submitted to ventricular-peritoneal shunt. A diagnostic arteriography was performed with 3D reconstruction, which showed evidence of fenestration of the basilar artery associated with aneurysm in the right vertebrobasilar portion. An aneurysm coil embolization was performed without complications. The patient was discharged 19 days later maintaining diplopia, with paralysis of the left sixth cranial nerve, but without any other complaints or neurological symptoms.

Discussion Fenestration of the basilar artery occurs due to failure of fusion of the longitudinal neural arteries in the embryonic period, and it is associated with the formation of aneurysms. The endovascular treatment is the first choice and several techniques are described, including simple coiling, balloon remodeling, stent-assisted coiling, liquid embolic agents and flow diversion devices. The three-dimensional rotational angiography (3DRA) is an extremely helpful tool when planning the best treatment course.

Conclusion Fenestrated basilar artery aneurysms are rare and complex vascular diseases and their treatment improved with the advent of the 3D angiography and the development of the endovascular techniques.
\end{abstract}

received

July 23, 2017

accepted

October 17, 2017
DOI https://doi.org/

$10.1055 / \mathrm{s}-0037-1608883$.

ISSN 0103-5355.
Copyright $\odot 2017$ by Thieme Revinter

Publicações Ltda, Rio de Janeiro, Brazil
License terms

(1) (1) $\Theta \circledast$ 


\section{Resumo}

Palavras-chave
- aneurisma
intracraniano
- hemorragia
subaracnoide
- angiografia cerebral
- fenestração

Introdução Aneurismas da junção vertebrobasilar são raros, mas quando presentes, geralmente estão associados à fenestração da artéria basilar. Frequentemente, o tratamento endovascular é a primeira opção devido à complexidade da anatomia da fossa posterior, o que representa um obstáculo para a alternativa de tratamento com cirurgia aberta.

Relato de Caso Um homem de 47 anos de idade deu entrada na unidade de emergência com cefaleia, diplopia, dor no pescoço e desorientação. O exame neurológico mostrou: 15 pontos na escala de coma Glasgow (ECG), ausência de déficit motor ou de sensibilidade, paralisia do sexto nervo craniano I esquerdo, Hunt-Hess grau III. A tomografia computadorizada apresentou hemorragia subaracnoidea (Fisher grau III) e hidrocefalia. O paciente foi submetido a shunt ventricular-peritoneal. A arteriografia diagnóstica foi feita com reconstrução 3D, que comprovou fenestração da artéria basilar associada a aneurisma na porção vertebrobasilar direita. Realizamos embolização do aneurisma com molas, sem complicações. O paciente recebeu alta 19 dias depois, mantendo diplopia, paralisia do sexto nervo craniano esquerdo, sem outras complicações ou sintomas neurológicos.

Discussão A fenestração da artéria basilar ocorre devido à falência da fusão das artérias neurais longitudinais no período embrionário e está associada à formação de aneurismas. O tratamento endovascular é a primeira opção e várias técnicas são descritas, incluindo simples embolização, remodelagem por balão, embolização assistida com stent, agentes embólicos líquidos e dispositivos de desvio de fluxo. Para planejar o melhor tratamento, angiografias rotacionais 3D são extremamente úteis.

Conclusão Aneurismas de artéria basilar fenestrada são doenças vasculares raras e complexas, e seu tratamento foi aprimorado com o advento de angiografias 3D e desenvolvimento de técnicas endovasculares.

\section{Introduction}

Fenestration of the basilar artery is presented in $0.6 \%$ to $2.3 \%$ of angiographies and in $\sim 1-5 \%$ of autopsies. ${ }^{1,2}$ It can occur anywhere along the basilar artery, but it is more common near the vertebrobasilar junction. Saccular aneurysms of the vertebrobasilar junction are rare, but when present, they are often associated with fenestration of the basilar artery. ${ }^{1}$ Such variation occurs due to failure of fusion of the longitudinal neural arteries in the embryonic period. The complex anatomy of the region makes endovascular treatment the first choice in most cases. The present study aims to report the case of a patient with aneurysm associated with fenestration of the basilar artery; his treatment and follow-up= took place at a university hospital in São Paulo. The study also aims to make a brief review on the topic.

\section{Case Report}

A 47-years-old man was admitted to the emergency unit of our hospital presenting with headache, diplopia, neck pain and mental confusion ongoing for 3 days. The patient was transferred from another service with a CT scan showing subarachnoid hemorrhage (Fisher III) associated with hydrocephalus (-Fig. 1).
At admission, the patient had stable vital signs, he was conscious and oriented, his Glasgow coma scale (ECG) score was 15 , and he did not present any motor or sensitive deficit, no pupillary alteration, but had palsy of the left sixth cranial nerve and Hunt- Hess grade III.

The patient was submitted to implantation of a ventricularperitoneal shunt on the same day of the admission and referred to the ICU without neurological deterioration. A diagnostic angiography was performed with 3D reconstruction (-Fig. 2 ), which showed evidence of fenestration of the basilar artery associated with aneurysm in the right vertebrobasilar portion. An aneurysm coil embolization was performed (-Fig. 3) without complications.

The patient was discharged 19 days later, maintaining diplopia and paralysis of the left sixth cranial nerve, but without any other complaints or neurological symptoms.

\section{Discussion}

The basilar site is the second most common site of intracranial fenestration, after the anterior communicating artery. ${ }^{3}$ Fenestration of the basilar artery is a recognized vascular variation with dual endothelium-lined vascular lumens, which is usually caused by a failure of fusion of the paired longitudinal neural arteries during the fifth week of embryonic life. ${ }^{1,2}$ The elastin 


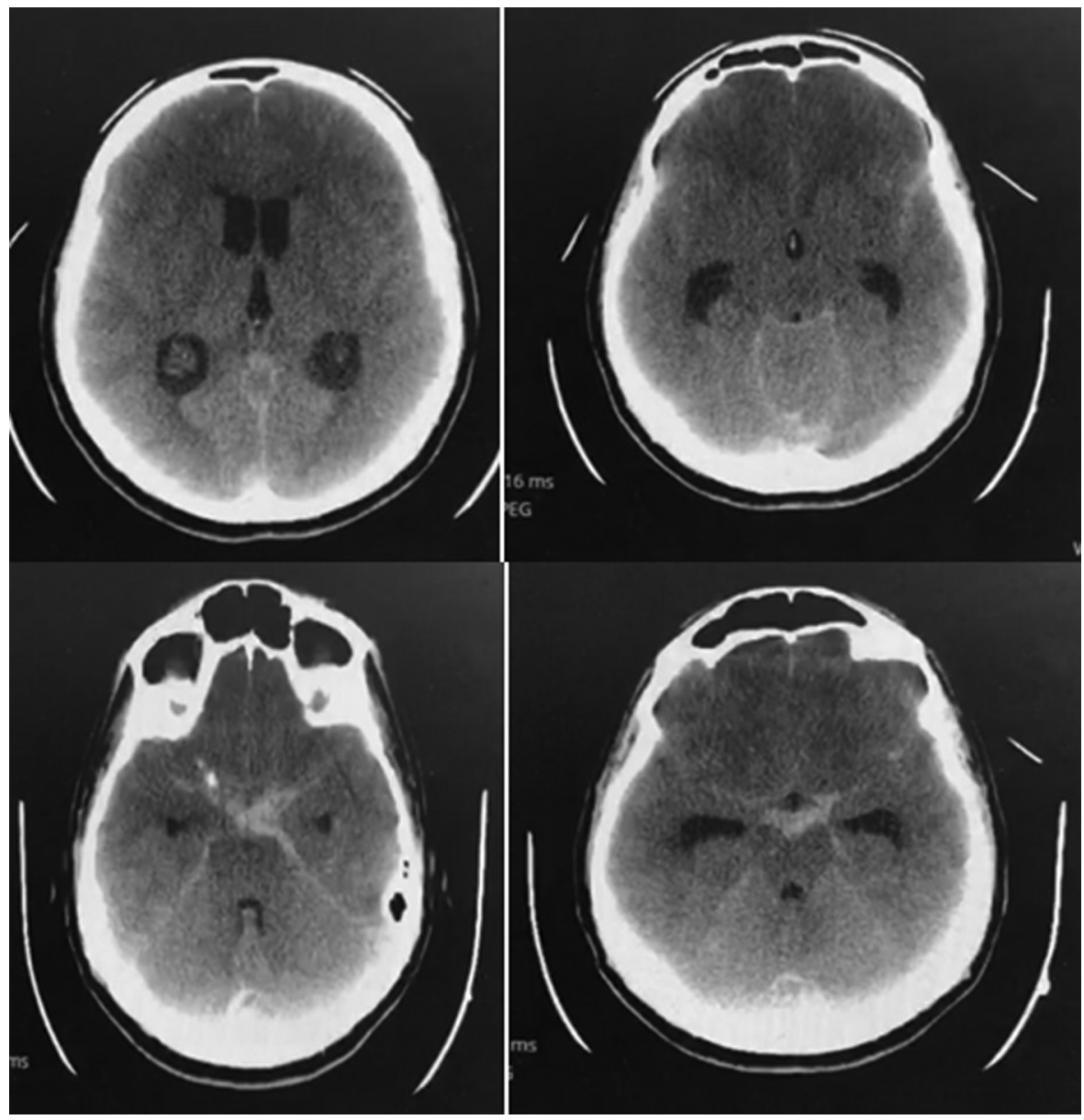

Fig. 1 CT scan with subarachnoid hemorrhage (SAH) (Fisher III) and hydrocephalus.

defect in the tunica media combined with a pro-inflammatory state, weakening the arterial wall at the distal and proximal edges of the fenestration and associated with the alteration in the blood flow hemodynamics, are responsible for the development of an aneurysm at the vertebrobasilar fenestrated

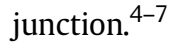

The location of these aneurysms is proximal to the brainstem, and the wide varieties of the fenestrations complex and the presence of perforator vessels make the microsurgical approach extremely dificcult. ${ }^{1,2,8-10}$ An endovascular-based approach is becoming the first-line treatment, and meticulous preprocedural planning is extremely important to study the exact anatomy of the aneurysm-fenestration complex to determine the most appropriate endovascular therapeutic technique, Therefore, the three-dimensional rotational angiography (3DRA) is an extremely helpful tool to plan the endovascular treatment. ${ }^{11}$

Kai et al proposed two types of classification. Type A has a bridging artery between the distal V4 portions of both vertebral arteries. The resulting fenestration showed a somewhat triangular shape. Type B does not have a bridging artery and it is a somewhat elliptical fenestration. ${ }^{9}$ With the improvement of the 3-dimensional angiographic technology and of the endovascular technique, Trivelato et al proposed a new classification based on the aneurysm neck size and on the base of implantation in the proximal bifurcation of the fenestration, which allowed for therapeutic planning by selecting the most adequate modality of endovascular technique. The four types are described as follows: $1 \mathrm{~A}$ : narrow neck, symmetric at the bifurcation. 1B: narrow neck, spares one loop. 2A: wide neck, involves both loops. 2B: wide neck, spares one loop. ${ }^{2}$

Several endovascular techniques are described, including simple coiling, balloon remodeling technique, stent-assisted coiling, liquid embolic agents and flow diversion devices. The literature shows that the majority of the fenestrated basilar artery aneurysms was treated with simple coiling (78.2\%), even those with wide necks. This could be explained because many patients were treated before the development of the balloon remodeling and the stent-assisted coiling techniques. ${ }^{2,3}$

$\mathrm{T}$ case reported shows an aneurysm of the fenestrated proximal basilar artery, type B, as per Kai et al/type 1B as per Trivelato et al, treated by endovascular technique using simple coil with a good angiographic and clinical outcome.

\section{Conclusion}

Fenestrated basilar artery aneurysms are rare and complex vascular diseases. Endovascular treatment is the first option due to the intricate posterior fossa anatomy that is a challenge for the open surgical treatment. With the advent of the 3D 


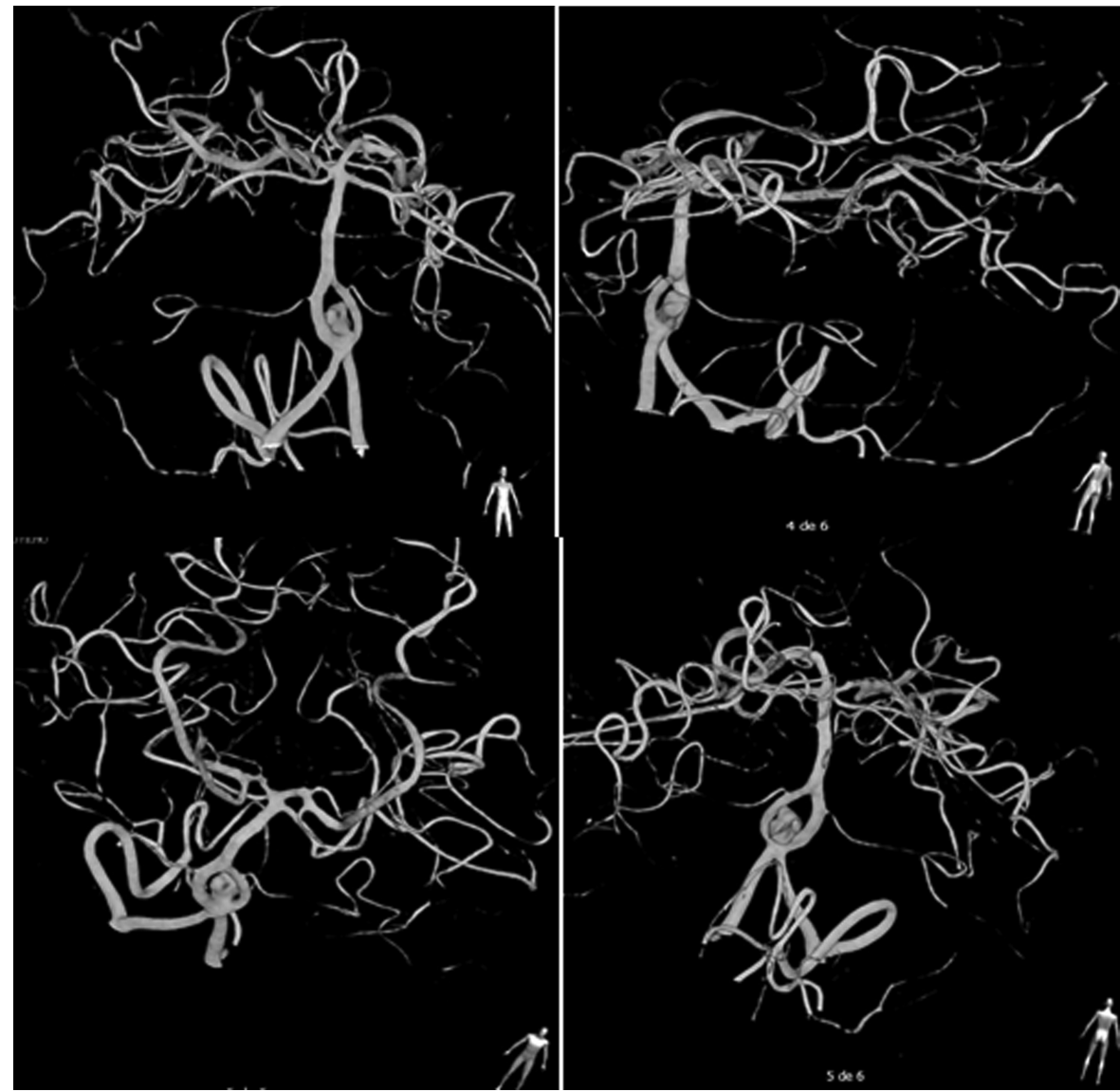

Fig. 2 3D-angiography showing aneurysm of the fenestrated basilar artery.

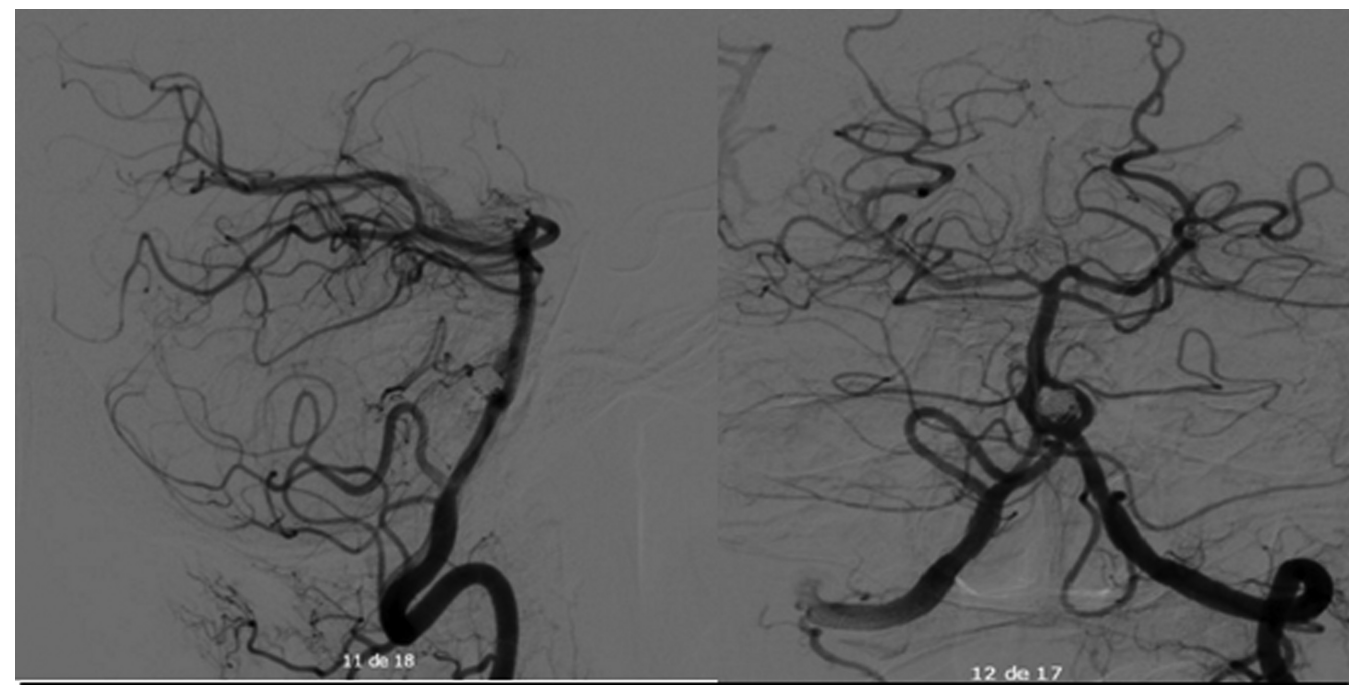

Fig. 3 Post-embolization arteriography with coils.

angiography, a range of endovascular modalities emerged that led to the individualization of the treatment of aneurysms showing promising results.

\section{Conflict of Interest}

None.

\section{References}

1 Tanaka S, Tokimura H, Makiuchi T, et al. Clinical presentation and treatment of aneurysms associated with basilar artery fenestration. J Clin Neurosci 2012;19(03):394-401

2 Trivelato FP, Abud DG, Nakiri GS, et al. Basilar artery fenestration aneurysms: endovascular treatment strategies based on 3D morphology. Clin Neuroradiol 2016;26(01):73-79 
3 Park WB, Sung JH, Huh J, et al. Double Stent Assist Coiling of Ruptured Large Saccular Aneurysm in Proximal Basilar Artery Fenestration. J Cerebrovasc Endovasc Neurosurg 2015;17(03):227-233

4 Andrews BT, Brant-Zawadzki M, Wilson CB. Variant aneurysms of the fenestrated basilar artery. Neurosurgery 1986;18(02):204-207 [PubMed]

5 De Caro R, Serafini MT, Galli S, Parenti A, Guidolin D, Munari PF. Anatomy of segmental duplication in the human basilar artery. Possible site of aneurysm formation. Clin Neuropathol 1995;14(06):303-309

6 Islak C, Kocer N, Kantarci F, Saatci I, Uzma O, Canbaz B. Endovascular management of basilar artery aneurysms associated with fenestrations. AJNR Am J Neuroradiol 2002;23(06):958-964

7 Tasker AD, Byrne JV. Basilar artery fenestration in association with aneurysms of the posterior cerebral circulation. Neuroradiology 1997;39(03):185-189 [PubMed]
8 Alqahtani SA, Felbaum DR, Tai A, Liu AH, Armonda RA. Endovascular Treatment of Large Unruptured Fusiform Fenestrated Vertebrobasilar Junction Aneurysm. Cureus 2017;9(05):e1219 10.7759/cureus.1219

9 Kai Y, Hamada J, Morioka M, Yano S, Fujioka S, Kuratsu J. Endovascular treatment of ruptured aneurysms associated with fenestrated basilar artery. Two case reports. Neurol Med Chir (Tokyo) 2006;46(05):244-247 10.2176/nmc.46.244

10 Albanese E, Russo A, Ulm AJ. Fenestrated vertebrobasilar junction aneurysm: diagnostic and therapeutic considerations. J Neurosurg 2009;110(03):525-529 10.3171/2008.9.JNS08170

11 Consoli A, Renieri L, Nappini S, et al. Endovascular treatment with 'kissing' flow diverter stents of two unruptured aneurysms at a fenestrated vertebrobasilar junction. J Neurointerv Surg 2013;5 (02):e9 